\title{
Potensi Padang Lamun (Thalassia hemprichii) Sebagai Penyimpan dan Penyerap Karbon di Pantai Krakal, Gunungkidul, Yogyakarta
}

\author{
Rini Pramesti, Subagiyo, Wilis Ari Setyati, Titis Buana* \\ Departemen Ilmu Kelautan, Fakultas Perikanan dan Ilmu Kelautan, Universitas Diponegoro \\ Jl. Prof. H. Soeadarto S.H, Tembalang, Semarang, Jawa Tengah 50275 Indonesia \\ Email: inibuanatitis@gmail.com
}

\begin{abstract}
Abstrak
Padang lamun merupakan ekosistem pesisir yang mampu menyimpan dan menyerap karbon melalui proses fotosintesis yang disimpan dalam bentuk biomassa dan disimpan di akar, rhizome dan daun sehingga dapat mengurangi gas $\mathrm{CO}_{2}$ di udara. Ekosistem ini belum banyak diperhatikan fungsinya dibandingkan dengan ekosistem darat. Penelitian ini bertujuan mengetahui kerapatan, tutupan lamun dan serapan karbon dalam biomassa berupa jaringan atas substrat dan bawah substrat. Penelitian dilakukan pada bulan November 2018 di Pantai Krakal - Yogyakarta. Identifikasi jenis lamun dengan buku panduan seagrasswatch, kerapatan dan tutupan dengan metode line transect quadrant. Analisis kandungan karbon menggunakan metode pengabuan. Hasil penelitian menunjukkan lokasi ini memiliki biomassa di bagian atas 7,36-9,92 gbk $/ \mathrm{m}^{2}$ dan bagian bawah 39,36 - 95,68 gbk $/ \mathrm{m}^{2}$. Kedua bagian ini mampu menyimpan dan menyerap karbon ratarata sebesar $30,42 \pm 13,85 \mathrm{gC} / \mathrm{m}^{2}$ dan $0,2 \pm 0,06 \mathrm{gC} / \mathrm{d} / \mathrm{m}^{2}$. Hasil penelitian menunjukkan padang lamun di lokasi ini mampu menyimpan dan menyerap karbon meskipun dalam jumlah yang kecil.
\end{abstract}

Kata kunci : Perubahan Iklim, Thalassia hemprichii, Simpanan Karbon, Serapan Karbon, Pantai Krakal.

\section{Abstract \\ Carbon Storage and Absorption Rate of Seagrass beds (Thalassia hemprichii) in Pantai Krakal, Gunungkidul - Yogyakarta}

Seagrass beds are coastal ecosystems capable of absorbing and storing carbon through photosynthesis and stored of roots, rhizomes and leaves that it can reduce $\mathrm{CO} 2 \mathrm{gas}$ in the air. The function of this ecosystem has not been given much attention compared to the terrestrial ecosystem. The research was studied to determine density, cover of seagrass and carbon uptake in biomass of the upper and lower substrate. The research was carried in November 2018 at Krakal Beach - Yogyakarta. Identification of the type seagrass was carried by seagrasswatch manual, the density and cover was carried by the line transect quadrant method. The carbon content was analysis by the ashing method. The results was showed that this location has a biomass at the top of $7.36-9.92 \mathrm{gbk} / \mathrm{m}^{2}$ and the bottom of $39.36-95.68 \mathrm{gbk} / \mathrm{m}^{2}$. Both of these parts are able to store and absorb carbon are average of $30.42 \pm 13.85 \mathrm{gC} / \mathrm{m}^{2}$ and $0.2 \pm 0.06 \mathrm{gC} / \mathrm{d} / \mathrm{m}^{2}$. The results showed that the seagrass beds on this beach were able to store and absorb of carbon with small amounts.

Keywords : Climate change, Thalassia hemprichii, Carbon storage, Carbon absorption rate, Pantai Krakal.

\section{PENDAHULUAN}

Perubahan iklim dapat disebabkan meningkatnya kandungan Gas Rumah Kaca seperti (karbon dioksida (CO2), klorofluorokarbon (CFC), ozon (O3), dinitro oksida $\left(\mathrm{N}_{2} \mathrm{O}\right)$, metana $(\mathrm{CH} 4)$, heksafluorida
(SF6), hidrofluorokarbon (HFCS), perfluorokarbon (PFCS). Diantara kedelapan gas tersebut, konsentrasi gas $\mathrm{CO} 2$ di atmosfer memiliki kontribusi terbesar yaitu lebih dari 55\% dari total efek GRK yang ditimbulkan. Salah satu 
upaya pencegahan yang dilakukan untuk menurunkan emisi GRK dengan memanfaatkan lautan dan ekosistem pesisir sebagai penyerap $\mathrm{CO}_{2}$ alami (natural $\mathrm{CO}_{2}$ sink) (Sabine et al., 2004; Kawaroe, 2009). Salah satu ekosistem pesisir ini adalah padang lamun (Jiang et al., 2017). Ekosistem ini dapat menyerap 83.000 metrik ton karbon $/ \mathrm{km}^{2}$, jumlah ini lebih tinggi dibandingkan kemampuan hutan yang menyerap 30.000 metrik ton karbon $/ \mathrm{km}^{2}$ (Fourqurean et al., 2012).

Karbon di padang lamun dapat tersimpan lebih lama di bagian bawah substrat yaitu 10-50 kali dibandingkan karbon yang tersimpan di daratan sehingga peran lamun bertambah penting karena dapat tersimpan dalam jangka waktu yang lama (Kiswara, 2010). Lamun merupakan tumbuhan laut yang berkontribusi terhadap penyerapan karbon melalui proses fotosintesis yang disimpan dalam bentuk biomassa pada bagian daun, rhizoma dan akar dalam satuan $\mathrm{gbk} / \mathrm{m} 2$ (gram berat kering per meter persegi. Biomassa ini dipengaruhi oleh umur tegakan, komposisi, struktur tegakan dan perkembagan vegetasi (Kusmana et al.,1992).

Padang lamun berperan sebagai penyerap karbon seperti hutan dan perkebunan pada awalnya kurang diperhatikan karena penelitian banyak tertuju pada tanaman darat, sehingga peran ekosistem pesisir diabaikan. Hal ini karena terbatasnya vegetasi pesisir yang hanya kurang dari $2 \%$ dari permukaan lautan (Duarte et al., 2005). Padahal vegetasi ini dapat menjaga keseimbangan penyerapan dan pengurangan emisi karbon (Silva et al., 2009; Kennedy et al., 2010).

Penelitian tentang simpanan dan serapan karbon di padang lamun sudah banyak dilakukan (Rahmawati \& Kiswara (2012) di Pulau Pari Jakarta, Rustam et al. (2015) di Tanjung Lesung Banten, Graha et al. (2015) di Pantai Sanur Bali, Alongi et al. (2016) di Perairan Indonesia, Irawan (2017) di Bagian Timur dan Utara Pulau Bintan. Pantai Krakal merupakan salah satu pantai wisata yang terletak di Selatan Jawa Kabupaten Gunul Kidul yang berarus kuat (Hutomo et al., 2009) dan memiliki beranekaragam biota laut dan salah satunya tanaman lamun (Pangururan et al., 2015). Penelitian yang telah dilakukan di lokasi ini yaitu jenis-jenis Echinodermata (Yusron, 2015); rumput laut (Pramesti et al., 2016 ; Aziz \& Chasani, 2020), bulu babi (Prasetyo et al., 2019). Informasi tentang simpanan dan serapan karbon khususnya lamun di lokasi ini diduga belum ada, sehingga penelitian ini perlu dilakukan.

Tujuan penelitian ini untuk mengetahui jenis lamun, kerapatan dan tutupan lamun, nilai biomassa dan estimasi simpanan karbon dalam biomassa pada lamun yang berupa jaringan dibagian atas substrat (daun) dan dibagian bawah substrat (akar dan rhizoma) di Pantai Krakal, Yogyakarta.

\section{MATERI DAN METODE}

Materi penelitian ini adalah sampel lamun ( $T$. hemprichii) yang diambil dari Pantai Krakal, Gunung Kidul - Yogyakarta pada tanggal 15 sampai 20 November 2018 yang selanjutnya diuji laboratorium pada tanggal 22 November sampai 1 Desember 2018 di Laboratorium Geologi Dasar Fakultas Perikanan dan Ilmu Kelautan, Universitas Diponegoro. Adapun lokasi stasiun penelitian (Gambar 1).

Penelitian terbagi dalam 3 Stasiun yaitu Stasiun 1 (Bagian Barat), Stasiun 2 (Bagian Tengah), dan Stasiun 3 (Bagian Timur). Lokasi penelitian ini dipilih karena pertimbangan tingkat persentase tutupan vegetasi lamun. Stasiun I mempunyai persentase tutupan lamun tinggi, Stasiun II dengan persentase tutupan lamun rendah dan Stasiun III persentase tutupan lamunnya sedang. Parameter yang diamati meliputi jenis, kerapatan dan persentase tutupan lamun. Pengambilan dilakukan dengan mencuplik lamun yang terdapat di transek kuadran berukuran $50 \times 50 \mathrm{~cm}$ dan dibagi menjadi 4 sub plot bagian yang lebih kecil (Hutomo et al, 2009). Pengamatan lamun dengan buku identifikasi lamun mengacu pada Seagrasswatch manual book (Mc Kenzie et al., 2003). Pengambilan sampel dilakukan sampai pada kedalaman penetrasi akar dan pemotongan rhizome yang menjalar kesamping (batas luar kuadran / transek) kemudian dibersihkan. Masing - masing pencuplikan dengan tiga ulangan dan sampel yang diperoleh ini sebagai herbarium basah. Sampel dipisah pada bagian akar, rhizome dan daun kemudian dipotong dan ditimbang berat basahnya (Graha et al., 2015) dan nilai biomassa setiap jaringan dihitung dari berat basah dan berat keringnya.

Kandungan karbon yang ada di sampel (akar, rhizome dan daun) dianalisis dengan metode LOI (Loss on Ignition) atau pengabuan (Helrich, 1990). Cawan dimasukkan ke dalam 
tanur listrik $\pm 2-3$ jam pada suhu $550^{\circ} \mathrm{C}$ dan didinginkan \pm 30 menit dalam desikator. Sebanyak 1-2 gram dimasukkan dalam tanur listrik selama 6 jam pada suhu $550^{\circ} \mathrm{C}$ hingga menjadi abu yang ditandai dengan perubahan warna menjadi warna putih keabuan tanpa adanya bintik hitam.

\section{Analisa data}

Perhitungan kerapatan lamun menggunakan rumus (Khouw, 2009):

$$
\mathrm{Di}=\frac{\sum \mathrm{ni}}{\mathrm{Ai}}
$$

Keterangan : $\mathrm{Di}=$ Kerapatan lamun jenis-i (ind $\left./ \mathrm{m}^{2}\right) ; \Sigma \mathrm{n}=$ Jumlah tunas jenis- $\mathrm{i}$ (ind); $\mathrm{Ai}=$ Jumlah luas daerah dimana lamun jenis-i diketemukan $\left(\mathrm{m}^{2}\right)$

Penutupan jenis lamun pada tiap petaknya menggunakan rumus (Saito dan Adobe, 2004)

$$
\mathrm{C}=\frac{\sum(\mathrm{Mix} \mathrm{fi})}{\sum \mathrm{fi}}
$$

Keterangan: $\mathrm{C}=$ Persentase penutupan lamun jenis $\mathrm{i} ; \mathrm{Mi}=$ Prosentase titik tengah dari kelas kehadiran jenis lamun $\mathrm{i}$; $\mathrm{fi}=$ Banyaknya sub petak dengan kelas kehadiran jenis lamun i sama.

Perhitungan indeks keanekaragaman dilakukan berdasarkan rumus Shannon-Weinner (Odum, 1993):

$$
\begin{gathered}
\mathrm{H}^{\prime}=\sum_{i=1}^{n}\left(p i \log ^{2} p i\right) \\
p i=\frac{n i}{N}
\end{gathered}
$$

Keterangan: $\mathrm{H}^{\prime}=$ Indeks keanekaragaman; $\mathrm{Pi}=$ Frekuensi jenis ke-1 terhadap jumlah total; $\mathrm{N}=$ Jumlah total individu; $\mathrm{ni}=$ Jumlah individu jenis ke-i

Perhitungan indeks keseragaman dihitung dengan menggunakan rumus (Odum, 1993):

$$
\begin{gathered}
\mathrm{E}=\frac{\mathrm{H}^{\prime}}{\mathrm{H} \text { maksimum }} \\
\mathrm{H} \text { maksimum }=\log ^{2} S
\end{gathered}
$$

Keterangan: $\mathrm{E}=$ Jumlah keseragaman; $\mathrm{S}=$ Jumlah jenis

Indeks dominansi dihitung untuk mengetahui dominansi suatu spesies di wilayah penelitian. Perhitungan indeks dominansi dilakukan dengan rumus (Odum, 1993):

$$
\mathrm{D}=\sum_{\mathrm{i}=1}^{\mathrm{n}} \mathrm{Pi}^{2}
$$

Keterangan: $\mathrm{D}=$ Indeks Dominansi Simpson; Pi $=$ Frekwensi jenis ke-i terhadap jumlah total

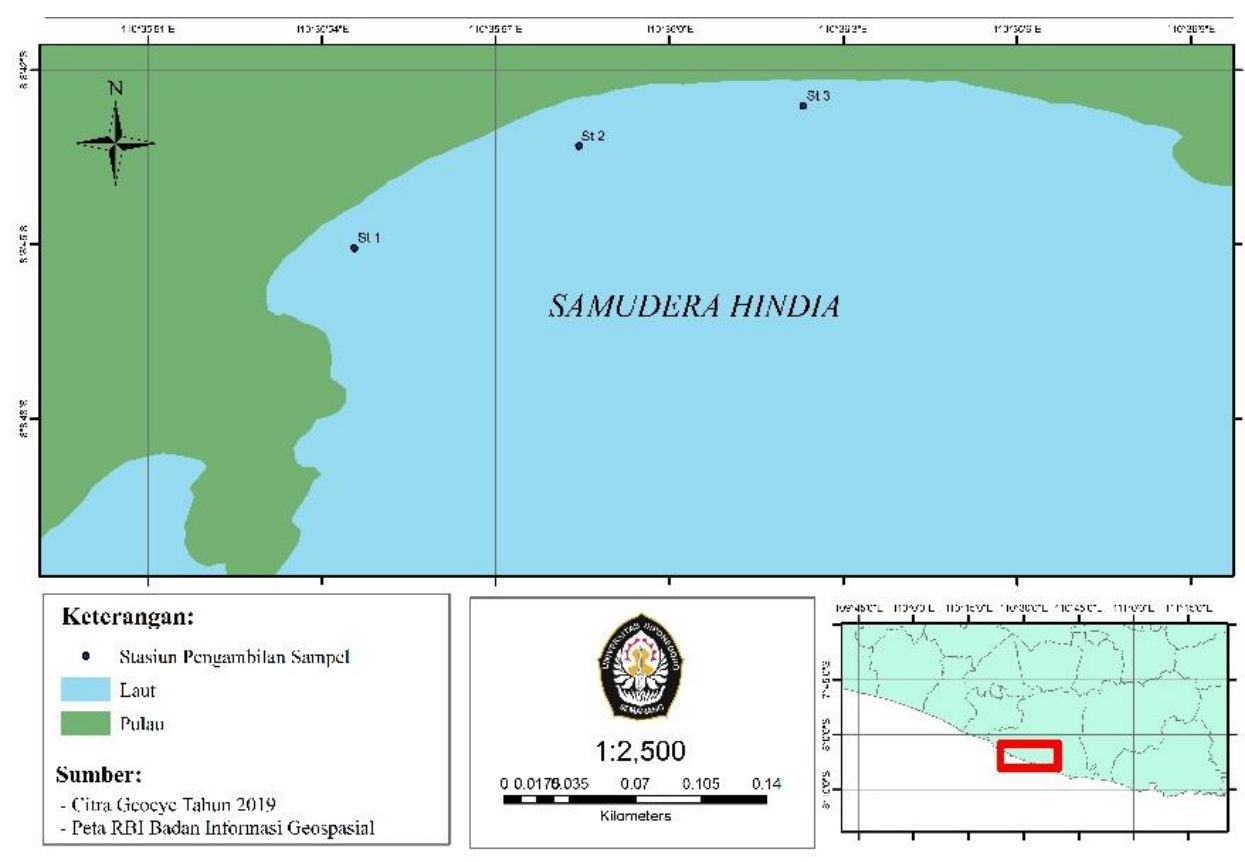

Gambar 1. Peta Lokasi Penelitian 
Pengukuran ini menggunakan rumus menurut Duarte (1990)

$$
\mathrm{B}=\mathrm{W} \times \mathrm{D}
$$

Keterangan $: \mathrm{B}=$ Biomassa lamun; $\mathrm{W}=$ Berat kering sebuah tunas lamun (gram $\mathrm{x}$ tunas. $\mathrm{m}^{2}$ ); $\mathrm{D}=$ Kepadatan lamun (tunas. $\mathrm{m}^{2}$ )

Pengukuran karbon lamun dengan menggunakan rumus (Helrich, 1990) :

$$
\text { Kadar abu }=\frac{c-a}{b-a} \times 100 \%
$$

Keterangan: $\mathrm{a}=$ Berat cawan; $\mathrm{b}=$ Berat cawan + berat kering jaringan lamun; $\mathrm{c}=$ Berat cawan + berat abu jaringan lamun

Perhitungan bahan organik dihitung dengan metode pengabuan dan ditentukan dengan menghitung pengurangan berat saat pengabuan (Helrich, 1990) dengan rumus:

$$
\text { Kadar Bahan Organik }=\frac{(b-a)-(c-a)}{(b-a)} \times 100 \%
$$

Keterangan: $\mathrm{a}=$ Berat cawan; $\mathrm{b}=$ Berat cawan + berat sampel; $\mathrm{c}=$ Berat $($ cawan $+\mathrm{abu})$

Nilai kandungan karbon jaringan dilakukan setelah mengetahui kadar bahan organik (Helrich, 1990)

$$
\text { Kadar Karbon }=\frac{\text { Kadar Bahan Organik }}{1,724}
$$

Keterangan: 1, $724=$ Konstanta Nilai Bahan Organik

Nilai Simpanan Karbon lamun dihitung menurut (Sulaeman et al., 2005)

$$
\mathrm{Ct}=\Sigma(\mathrm{Li} \times \mathrm{ci})
$$

Keterangan : $\mathrm{Ct}=$ karbon total (ton); $\mathrm{Li}=$ luas padang lamun kategori kelas - $\mathrm{i}(\mathrm{m} 2) ; \mathrm{Ci}=$ ratarata stok karbon lamun kategori kelas - i ( $\mathrm{gC} / \mathrm{m} 2)$

\section{HASIL DAN PEMBAHASAN}

Hasil penelitian di semua stasiun hanya ditemukan satu jenis lamun (monospesifik) yaitu T. hemprichii dengan penyebaran tidak merata dan jenis substrat sama yaitu pasir kasar. Hal ini sesuai (Sakey et al., 2015) menyatakan lamun $T$. hemprichii dapat membentuk padang lamun monospesifik pada substrat karang mati atau di pasir kasar dan (Yusron, 2015) menyatakan jenis lamun yang mendominasi di Pantai Gunung Kidul adalah T.hemprichii. Daun berukuran kecil 3 - 15 $\mathrm{cm}$. Jarak terjauh ditemukannya lamun pada stasiun 1 yaitu $30 \mathrm{~m}$ tegak lurus garis pantai, sedangkan jarak terdekatnya $0 \mathrm{~m}$ yaitu titik pertama ditemukannya lamun. Nilai kerapatan dan persentase tutupan lamun bervariasi. Nilai kerapatan tertinggi di stasiun 3 yaitu $676 \mathrm{ind} / \mathrm{m}^{2}$ dengan persentase tutupan $95 \%$. Nilai terendah pada stasiun 1 yaitu $12 \mathrm{ind} / \mathrm{m}^{2}$ dan persentase tutupan 5\% (Tabel 1).

Pada Tabel 1. menunjukkan ketiga stasiun mempunyai nilai kerapatan dan persentase tutupan dengan nilai yang bervariasi. Hal ini diduga pada setiap stasiun memiliki karakteristik yang berbeda. Stasiun 1 terletak di ujung bagian barat, lokasi ini terhalang daratan yang menjorok ke lautan sehingga gelombang yang sampai ke bibir pantai lebih tenang karena gelombang diredam daratan. Kondisi perairan yang tenang ini merupakan salah satu karakteristik habitat yang sesuai untuk pertumbuhan lamun. Stasiun 2 berada di tengah garis pantai, yang memiliki kerapatan terendah karena di lokasi ini merupakan pusat kegiatan wisata. Stasiun 3 tidak memiliki penghalang gelombang, sehingga gelombang langsung menghantam bibir pantai. T. hemprichii yang diketemukan di lokasi mempunyai panjang daun yang kecil $(10-15 \mathrm{~cm})$ padahal Susetiono (2004) menyatakan panjang daun T. hemprichii adalah $10-20 \mathrm{~cm}$. Hal ini diduga merupakan salah satu cara adaptasi lamun yang hidup di perairan yang berarus kuat.

Nilai rata-rata persentase tutupan lamun pada stasiun 1 yaitu $21 \%$, stasiun 2 sebesar $9 \%$ dan stasiun 3 yaitu $6 \%$. Nilai tersebut termasuk kategori miskin. Hal ini diduga kondisi perairan yang berarus kuat, intensitas gelombang tinggi, sehingga lamun tidak dapat tumbuh optimal. Menurut KepMen LH No. 200 Tahun 2004, status padang lamun di suatu wilayah digolongkan menjadi 3 kategori yaitu persentase tutupan lamun apabila $\geq 60 \%$ dikategorikan kaya/sehat, nilai tutupan $30-59,9 \%$ termasuk kategori kurang kaya/kurang sehat dan jika persentase tutupannya $\leq 29,9 \%$ termasuk kategori miskin.

Nilai indeks ekologi pada lamun digunakan untuk melihat keseimbangan ekosistem lamun di 
setiap stasiun penelitian. Nilai indeks ekologi meliputi indeks keanekaragaman, indeks keseragaman dan indeks dominansi. Nilai keanekaragaman yang didapatkan di lokasi penelitian adalah $\mathrm{H}=0$, sehingga tidak ada keanekaragaman jenis lamun, karena diketemukan hanya 1 jenis yaitu T. hemprichii. Nilai keseragaman yang didapat dari ketiga stasiun adalah $\mathrm{E}=0$, sehingga keseragaman jenis lamun di lokasi ini tergolong rendah (Odum, 1998). Hasil perhitungan nilai indeks dominansi (D) sebesar 1, yang menunjukkan terdapat dominansi yang tinggi.

Berdasarkan hasil penelitian tentang biomassa lamun (Tabel 2.) menunjukkan nilai biomassa lamun di bagian atas substrat lebih rendah dibanding dengan bagian bawah substrat.
Hal ini diduga semakin banyak rhizome dan akar yang dapat menembus sedimen maka ruang poripori yang terdapat di sedimen semakin luas / banyak sehingga dapat membantu akar dalam menyerap nutrien dan memudahkan masuknya nutrisi. Hal lainnya diduga rhizome mengandung banyak zat pati hasil dari proses fotosintesis yang disimpan dibagian bawah substrat. Kandungan karbon di bawah substrat dipengaruhi faktor fisik lingkungan dibandingkan dengan kandungan karbon di atas substrat yang banyak dipengaruhi suhu dan salinitas. Hal ini diduga kandungan karbon bawah substrat dapat tersimpan lebih lama dan bertambah banyak. Nilai biomassa di bawah substrat merupakan gabungan dari akar dan rhizoma sehingga biomassanya cenderung lebih tinggi dibandingkan nilai

Tabel 1. Nilai Kerapatan (ind $/ \mathrm{m}^{2}$ ) dan Persentase Tutupan T. hemprichii (\%) di Pantai Krakal, Gunungkidul, Yogyakarta, 2018

\begin{tabular}{|c|c|c|c|c|c|c|c|}
\hline \multicolumn{7}{|c|}{ Stasiun 1} & \multirow{3}{*}{$\begin{array}{l}\text { Rata-Rata } \\
\% \text { Tutupan }\end{array}$} \\
\hline & \multicolumn{2}{|c|}{ Line 1} & \multicolumn{2}{|c|}{ Line 2} & \multicolumn{2}{|c|}{ Line 3} & \\
\hline Titik & $\begin{array}{c}\mathrm{Di} \\
\left.\text { (ind } / \mathrm{m}^{2}\right)\end{array}$ & $\begin{array}{c}\% \\
\text { Tutupan }\end{array}$ & Di (ind $/ \mathrm{m}^{2}$ ) & $\begin{array}{c}\% \\
\text { Tutupan }\end{array}$ & $\begin{array}{c}\mathrm{Di} \\
\text { (ind } / \mathrm{m}^{2} \text { ) }\end{array}$ & $\begin{array}{c}\% \\
\text { Tutupan }\end{array}$ & \\
\hline $0 \mathrm{~m}$ & 108 & 20 & 208 & 45 & 264 & 40 & \\
\hline $5 \mathrm{~m}$ & 56 & 10 & 636 & 90 & 408 & 70 & \\
\hline $10 \mathrm{~m}$ & - & - & 252 & 50 & 584 & 85 & \\
\hline $15 \mathrm{~m}$ & - & - & 12 & 5 & 620 & 90 & $21 \%$ \\
\hline $20 \mathrm{~m}$ & - & - & 240 & 40 & 612 & 85 & \\
\hline $25 \mathrm{~m}$ & - & - & 256 & 50 & - & - & \\
\hline \multirow[t]{2}{*}{$30 \mathrm{~m}$} & - & - & 32 & 5 & - & - & \\
\hline & & & \multicolumn{2}{|c|}{ Stasiun 2} & & & \\
\hline $0 \mathrm{~m}$ & 340 & 50 & 304 & 45 & 292 & 35 & $9 \%$ \\
\hline \multirow[t]{2}{*}{$5 \mathrm{~m}$} & 212 & 30 & - & - & 420 & 45 & \\
\hline & & & Stasiun 3 & & & & \\
\hline $0 \mathrm{~m}$ & 224 & 40 & 388 & 60 & 116 & 20 & \\
\hline $5 \mathrm{~m}$ & 676 & 95 & - & - & 452 & 55 & $6 \%$ \\
\hline $10 \mathrm{~m}$ & - & - & - & - & 116 & 30 & \\
\hline
\end{tabular}

Tabel 2. Biomassa Lamun T. hemprichii di Pantai Krakal, Gunungkidul - Yogyakarta, 2018

\begin{tabular}{cccc}
\hline \multirow{2}{*}{ Stasiun } & \multicolumn{2}{c}{ Biomassa $\left(\mathrm{gbk} / \mathrm{m}^{2}\right)$} & $\begin{array}{c}\text { Total Biomassa } \\
\left(\mathrm{gbk} / \mathrm{m}^{2}\right)\end{array}$ \\
\cline { 2 - 3 } & $\begin{array}{c}\text { Atas Substrat } \\
\text { (Daun) }\end{array}$ & $\begin{array}{c}\text { Bawah Substrat } \\
(\text { Akar dan Rhizoma) }\end{array}$ & \\
\hline 1 & 9,92 & 95,68 & 105,6 \\
2 & 9,76 & 39,36 & 49,12 \\
3 & 7,36 & 41,92 & 49,28 \\
\hline
\end{tabular}


Tabel 3. Simpanan Karbon Lamun di Pantai Krakal, Gunungkidul - Yogyakarta, 2018

\begin{tabular}{ccccc}
\hline \multirow{3}{*}{ Stasiun } & \multicolumn{3}{c}{ Simpanan Karbon $\left(\mathrm{gC} / \mathrm{m}^{2}\right)$} & \multirow{2}{*}{ Total Karbon $\left(\mathrm{gC} / \mathrm{m}^{2}\right)$} \\
\cline { 2 - 4 } & Atas ubstrat & \multicolumn{2}{c}{ BawahSubstrat } & \\
\cline { 2 - 4 } & Daun & Akar \& Rhizoma & Sedimen & \\
\hline 1 & 2,68 & 43,06 & 0,65 & 46,39 \\
3 & 3,32 & 17,71 & 0,7 & 21,73 \\
3 & 3,09 & 19,28 & 0,77 & 23,14 \\
\hline
\end{tabular}

Tabel 4. Nilai Rata-rata Laju Serapan Karbon di Pantai Krakal - Yogyakarta, 2018

\begin{tabular}{ccccccc}
\hline \multirow{2}{*}{ Stasiun } & \multicolumn{3}{c}{$\begin{array}{c}\text { Karbon }\left(\mathrm{gC} / \mathrm{d} / \mathrm{m}^{2}\right) \\
\text { Tegakan }\end{array}$} & $\begin{array}{c}\text { Rata- } \\
\text { Rata }\end{array}$ \\
\cline { 2 - 6 } & 1 & 2 & 3 & 4 & 5 & 0,24 \\
I & 0,33 & 0,04 & 0,12 & 0,18 & 0,52 & 0,23 \\
II & 0,06 & 0,33 & 0,36 & 0,17 & - & 0,13 \\
III & 0,12 & 0,08 & 0,2 & - & - & 0 \\
\hline
\end{tabular}

biomassa di atas substrat yang hanya terdiri daun saja. Hal ini sesuai (Khairunnisa et al., 2018) biomassa lamun lebih besar tersimpan pada bagian bawah substrat dan (Wahyudi, 2017) hasil fotosintesis dan unsur haranya langsung didistribusikan ke akar. Biomassa yang ada di akar lamun digunakan untuk menancap di substrat dan untuk beradaptasi dengan lingkungan yang berarus kuat.

Hasil penelitian tentang total karbon (daun, akar, rhizoma dan sedimen) di semua stasiun (Tabel 3.) menunjukkan nilai tertinggi di stasiun 1 $=46,39 \mathrm{gC} / \mathrm{m}^{2}$ dan terendah di stasiun $2=21,73$ $\mathrm{gC} / \mathrm{m}^{2}$. Simpanan karbon tertinggi terdapat di bagian bawah substrat (akar dan rhizoma) $=43,06$ $\mathrm{gC} / \mathrm{m}^{2}$ dan nilai terendah pada bagian atas substrat (daun) di stasiun $1=2,68 \mathrm{gC} / \mathrm{m}^{2}$.

Nilai rata-rata simpanan karbon lamun sebesar 30,42 $\pm 13,85 \mathrm{gC} / \mathrm{m}^{2}$. Nilai ini lebih besar dibandingkan di Pantai Sanur, Bali yang memiliki rata-rata total karbon sebesar $21 \mathrm{gC} / \mathrm{m}^{2}$ (Graha et al., 2015). Hasil penelitian (Irawan, 2017), Pulau Bintan bagian Utara dan Timur memiliki simpanan karbon sebesar 133,24 - 133,71 gC/m ${ }^{2}$; Rahmawati (2011) di Pulau Pari sebesar 200,5 $\mathrm{gC} / \mathrm{m}^{2}$. Hal ini menunjukkan simpanan karbon yang ada di Pantai Krakal termasuk rendah. Nilai yang rendah ini diduga adanya tekanan lingkungan berupa arus kuat dan substrat pasir kasar. Rahadiarta et al. (2019) menyatakan substrat berperan dalam menyimpan karbon selain di biomassa. Hal lainnya adalah jenis substrat di lokasi ini adalah pasir kasar sehingga kurang efektif untuk mengikat karbon.

Hasil penelitian tentang laju serapan karbon di daun lamun (Tabel 4.) menunjukkan rata-rata karbon terbesar yang diserap terdapat di stasiun 1 yaitu $0,24 \mathrm{gC} / \mathrm{d} / \mathrm{m}^{2}$ dan terendah di terendah di stasiun 3 sebesar $0,13 \mathrm{gC} / \mathrm{d} / \mathrm{m}^{2}$. Serapan karbon dapat dipengaruhi jumlah karbondioksida di kolom air dan cahaya yang masuk. Karbon dioksida yang ada di perairan masuk melalui udara dan $\mathrm{CO}_{2}$ yang terlarut dipengaruhi suhu. $\mathrm{CO}_{2}$ yang larut akan lebih tinggi jika suhu permukaan laut rendah. Suhu dapat mempengaruhi fisiologi tumbuhan pada proses fotosintesis, laju respirasi, reproduksi dan pertumbuhan (McKenzie et al., 2001).

Hasil penelitian Irawan (2017), lamun jenis T. hemprichii di Pulau Bintan bagian Timur mampu menyerap karbon yang dikonversikan di daun sebesar $0,1 \mathrm{gC} / \mathrm{d} / \mathrm{m}^{2}$. Rata-rata laju serapan karbon lamun di Pantai Krakal berkisar 0,06 $0,52 \mathrm{gC} / \mathrm{d} / \mathrm{m}^{2}$. Hasil ini menunjukkan laju serapan karbon di lokasi ini lebih besar dibandingkan Pulau Bintan bagian Timur. Suhu permukaan laut di lokasi yaitu $28-29^{\circ} \mathrm{C}$ sehingga lokasi ini mampu melarutkan karbondioksida dan lamun dapat melakukan proses fotosintesis. Ditambahkan (McKenzie et al., 2001) lamun dapat tumbuh dengan baik pada suhu $25-30{ }^{\circ} \mathrm{C}$. 


\section{KESIMPULAN}

Padang lamun di Pantai Krakal, Gunungkidul - Yogyakarta mampu menyimpan dan menyerap karbon meskipun dalam jumlah yang kecil.

\section{Reference}

Aziz, L. \& Chasani, A.R. 2020. Perbandingan Struktur dan Komposisi Makroalga di Pantai Drini dan Pantai Krakal. Jurnal Kelautan. 13(2):2476-9991.

Alongi, D.M., Murdiyarso, D., Fourqurean, J.W., Kauffman, J.B., Hutahaean, A., Crooks, S., Lovelock, C.E., Howard, J., Herr, D., Fortes, M. \& Pidgeon, E. 2016. Indonesia's Blue Carbon: A Globally Significant and Vulnerable Sink for Seagrass And Mangrove Carbon. Wetlands Ecology and Management, 24(1):3-13. doi: 10.1007/s11273-015-9446-y

Duarte C.M., Middelburg, J.J. \& Caraco, N. 2005. Major Role of Marine Vegetation on The Oceanic Carbon Cycle. Biogeosciences 2:1-8.

Fourqurean, J.W., Duarte, C.M., Kennedy, H., Marba, N., Holmer, M., Matoe, M.A., Apostolaki, E., Kendrick, G.A., Jensen, D.K., McGlathery, K.J., \& Serrano, O. 2012. Seagrass Ecosystems as a Globally Significant Carbon Stock. Nature Geoscience, 5:505-509. doi: 10.1038/ngeo1477

Graha, Y. I., Arthana I, W., G. A. Karang. 2015. Simpanan Karbon Padang Lamun di Kawasan Pantai Sanur, Kota Denpasar. Jurnal Ecotrophic, 10(1):46-53 doi: 10.24 843/EJES.2016.v10.i01.p08

Helrich, K. 1990. Official Methods of Analysis, 15th Edition, The Association of Official Analytical Chemists Inc., Arlington. 1298 hal.

Hutomo, M., Bengen, D,G., Kuriandewa T, E., Taurusman A.A. \& Handayani, E.B.S. 2009. Peran Ekosistem Lamun dalam Produktivitas Hayati dan Meregulasi Perubahan Iklim. Prosiding Lokakarya Nasional I Pengelolaan Ekosistem Lamun, 18 November 2009, Jakarta

Irawan, A. 2017. Potensi Cadangan dan Serapan Karbon Padang Lamun di Bagian Utara dan Timur Pulau Bintan. Jurnal Oseanologi dan
Limnologi Indonesia, 2(3):35-48. doi: 10.14 203/oldi.2017.v2i3.158

Jiang, Z., Liu, S., Zhang, J., Zhao, C., Wu, Y., Yu, S., Zhang, X., Huang, C., Huang, X. \& Kumar, J. 2017. Newly Discovered Seagrass Beds and Their Potential for Blue Carbon in the Coastal Seas of Hainan Island South China Sea. Marine Pollution Bulletin. doi: 10.1016/j.marpolbul.2017.07. 066

Kawaroe, M 2009. Luas Tutupan Lamun di Pulau Pari Berkurang. http:// www.coremap.or.id.

Keputusan Menteri Negara Lingkungan Hidup Nomor 200 Tahun 2004. Kriteria Baku Kerusakan dan Pedoman Penelitian Status Padang Lamun. $16 \mathrm{Hal}$

Kennedy H, Beggins J, Duarte C,M., Fourqurean, J.W., Holmer, J., Marbà, N \& Middelburg,J,J. 2010. Seagrass Sediments as a Global Carbon Sink: Isotopic Constraints, Global Biogeochem. Cycles, 24:GB4026, doi: 10.1029/2010GB003848.

Khairunnisa., Setyobudiandi, I. \& Boer, M. 2018. Estimasi Cadangan Karbon pada Lamun di Pesisir Timur Kabupaten Bintan. Jurnal Ilmu dan Teknologi Kelautan Tropis. 10(3):639650. doi: 10.29244/jitkt.v10i3.21397

Kusmana, C., Sabiham, S., Abe, K., Watanabe, H. 1992. An Estimation of Above Ground Tree Biomass of A Mangrove Forest in East Sumatra. Tropics, 1(4):143-257. doi: 10.3759/tropics.1.243

Khouw, A.S. 2009. Metode dan Analisa Kuantitatif dalam Bioteknologi Laut. Pusat Pembelajaran dan Pengembangan Pesisir dan Laut. Jakarta.

Kiswara, W. 2010. Studi Pendahuluan: Potensi Padang Lamun Sebagai Karbon Rosot dan Penyerap Karbon di Pulau Pari Teluk Jakarta. Oseanologi dan Limnologi di Indonesia 36 (3):361-376.

Mc Kenzie, Campbell, S.J. \& Roder, C.A. 2003. Seagrasswatch: Manual for Mapping and Monitring Seagrass Resources by Community (citizen) Volunteers. 2nd ed. The state of Queensland, Department of Primary Industries, CRC Reef, Queensland, pp 104. www.seagrasswatch.org (28 Januari 2019).

Odum, E.P. 1998. Dasar-dasar Ekologi. 3rd ed. Universitas Gadja Mada, Yogyakarta. 697 hal. 
Pramesti. R., AB. Susanto,AB., Setyati,W,. Ridlo,A.,Subagiyo., Oktaviaris, Y. 2016. Struktur Komunitas dan Anatomi Rumput Laut di Perairan Teluk Awur - Jepara dan Pantai Krakal, Yogyakarta. Jurnal Kelautan Tropis, 19(2):81-94, doi: 10.14710/jkt.v19i2. 822

Prasetyo, E., Zaida, A.A., Wulan, I.N., Wulandari, R., Santiati, E. \& Prakoso, C.N.Y. 2019. Kekayaan Jenis Bulu Babi (Sea Urchin) di Kawasan Perairan Pantai Gunung Kidul, Yogyakarta. Biospecies, 12(1):33-39. doi: 10.22437/biospecies.v12i1.6574

Rahmawati, S. \&Kiswara, W. 2012. Cadangan Karbon dan Kemampuan segbagai penyimpan Karbon Pada vegetasi Tunggal Enhalus acoroides di Pulau Pari, Jakarta. Jurnal Oseanologi dan Limnologi di Indonesia, 38(1):143-150.

Rahardiarta, I,K., Putra, I.D.N.N., Suteja, Y. 2019. Simpanan Karbon pada Padang Lamun di Kawasan Pantai Mengiat, Nusa Dua Bali. Journal of Marine and Aquatic Science, 5(1): 1-10. doi: 10.24843/jmas.2019.v05.i01.p01

Rahman, A., Nur, A,I. \& Ramli, M. 2016. Studi Laju Pertumbuhan Lamun (Enhalus acroides) di Perairan Pantai Desa Tanjung Tiram Kabupaten Konawe Selatan. Sapa Laut. 1 (1):10- 16

Rahmawati, S. 2011. Estimasi Cadangan Karbon pada Komunitas Lamun di Pulau Pari, Taman Nasional Kepulauan Seribu, Jakarta. Jurnal Segara, 7(1):1-12.

Rahmawati, S. \& Kiswara, W. 2012. Cadangan Karbon dan Kemampuan Sebagai Penyimpan Karbon Pada vegetasi Tunggal Enhalus acoroides di Pulau Pari - Jakarta. Oseanologi dan Limnologi di Indonesia 38(1):143-150

Rustam, A., Kepel, T. L., Kusumaningtyas, M. A., Ati, R.N.A., Daulat, A., Suryono, D.D., Sudirman, N., Rahayu, Y.P., Mangindaan, P.,
Heriati, A. \& Hutahean, A.A. 2015. Ekosistem Lamun Sebagai Bioindikator Lingkungan di Pulau Lembeh, Bitung, Sulawesi Utara. Jurnal Biologi Indonesia, 11(2):233-241. doi: 10.14203/jbi.v1 1i2.2197

Sabine, C.L., Feely, R.A., Gruber, N., Key, R.M., Lee, K., Bullister, J.L., Wanninkhof, R., Wong, C.S.L., Wallace, D.W., Tilbrook, B. and Millero, F.J., 2004. The oceanic sink for anthropogenic CO2. science, 305(5682), pp.367-371. doi: 10.1126/science.1097403

Silva, J., Sharon, Y., Santos, R. \& Beer, S. 2009. Measuring Seagrass Photosynthesis: Methods and Applications. Aquatic Biology, (7):127141.

Sakey, W.F., Wagey, B.T. \& Gerung, G.S. 2015. Variasi Morfometrik pada Beberapa Lamun di Perairan Semenanjung Minahasa. Jurnal Pesisir dan Laut Tropis, 1(1):1-7. doi: 10.35800/jplt.3.1.2015.7724.

Sulaeman, Suparto \& Eviati. 2005. Petunjuk Teknis Analisis Tanah, Tanaman, Air dan Pupuk. Balai Penelitian Tanah, Badan Penelitian dan Pengembangan Pertanian, Departemen Pertanian, Bogor.

Tasabaramo I.A., Mujizat, K. \& Rohani, A.R. 2015. Laju Pertumbuhan, Penutupan dan Tingkat Kelangsungan Hidup Enhalus acoroides yang Ditransplantasi Secara Monospecies dan Multispesies. Jurnal Ilmu dan Teknologi Kelautan Tropis, 7(2):757770 .

Yusron. E. 2015. Struktur Komunitas Ekhinoderma (Holothuroidea, Echinoidea dan Ophiuroidea) di Daerah Padang Lamun di Pantai Gunung Kudul, Yogyakarta. Zoo Indonesia Jurnal fauna Tropika. 24(2):73-82 doi: 10.52508/zi.v24i2.2334

Wahyudi, A.J. 2017. Menyerap Karbon: Layanan Ekosistem Untuk Mitigasi Perubahan Iklim. Gadjah Mada University Press. 42 hal. 